\title{
Total Quality Management in Islamic Education Institution
}

Idriyenni*)

Fakultas Ekonomi Universitas Putra Indonesia "YPTK" Padang

\begin{abstract}
Abstrak: There have been five characteristics of a qualified school such as focusing on the customer, total engagement, measurement, commitment, and continuous improvement. Every educational institution including Islamic boarding school (IBS) is required to provide the best services to its customers. In this way, IBS need to be supported by a good management system; the existence of a regular mindset (administrative thinking), the implementation of regular activities (administrative behavior), attitude to the task activities well (administrative attitude), and so forth. To answer the various problems that exist in the educational environment the management should have an Integrated or Total Quality Management (TQM). One of its goals is to transform a school institution into a sincere team, without conflict and internal competition to achieve a single goal of satisfying all customers. TQM will provide educators professional solutions to meet today's challenges and the future. It is because TQM can be used to build alliance between education, business and government. TQM can also shape the community responsive to the changing demands of society in this era of globalization. Besides, TQM form a responsive school and is able to respond to changes that occur in the field of education in order to give satisfaction to stakeholder.
\end{abstract}

Keywords: Management, Quality, Islamic education.

\section{PENDAHULUAN}

Pembangunan suatu bangsa tidak terlepas dari sistem pendidikan, sistem pendidikan yang baik akan membawa kemajuan bagi bangsa tersebut. Bangsa Indonesia sebagai negara yang sedang berkembang memiliki sistim pendidikan yang tertuang dalam Undang-Undang Nomor 20 Tahun 2003 Tentang Sistim Pendidikan Nasional Bab I, Pasal (1) yang berbunyi; Pendidikan adalah usaha sadar dan terencana untuk mewujudkan suasana belajar dan proses pembelajaran agar peserta didik secara aktif mengembangkan potensi dirinya untuk memiliki kekuatan spiritual keagamaan, pengendalian diri, kepribadian, kecerdasan, akhlak mulia, serta keterampilan yang diperlukan dirinya, masyarakat, bangsa dan negara.
Pendidikan merupakan proses yang bisa dilalui seseorang yang dapat membentuk mereka menjadi sumber daya yang berkualitas, sebagaimana tertuang dalam Undang-Undang Nomor 20 Tahun 2003 Bab.II pasal (3), bahwa fungsi dan tujuan pendidikan Nasional adalah : Pendidikan Nasional berfungsi mengembangkan kemampuan dan membentuk watak serta peradaban bangsa yang bermartabat dalam rangka mencerdaskan kehidupan bangsa, bertujuan untuk berkembangnya potensi peserta didik agar menjadi manusia yang beriman dan bertakwa kepada Tuhan Yang Maha Esa, berakhlak mulia, sehat, berilmu, cakap, kreatif, mandiri dan menjadi warga negara yang demokratis serta bertanggung jawab. 
Jadi masalah pendidikan ini merupakan masalah yang sangat penting dalam kehidupan manusia, karena maju tidaknya suatu bangsa sangat tergantung pada pendidikan bangsa tersebut,artinya jika pendidikan suatu bangsa dapat menghasilkan manusia yang berkualitas lahir bathin,maka bangsa tersebut akan maju, damai dan tentram sejahtera atau sebaliknya jika pendidikan suatu bangsa mengalami stagnasi maka bangsa itu akan terbelakang/tertinggal disegala bidang.

Berbicara mengenai kualitas sumber daya manusia,maka islam memandang bahwa pembinaan sumber daya manusia tidak dapat dilepaskan dari pemikiran mengenai manusia itu sendiri, dengan demikian Islam memiliki konsep yang sangat jelas, utuh dan komprehensif dalam pembinaan sumber daya manusia. Yang mana konsep ini tetap ini tetap dan relevan untuk diaplikasikan sepanjang zaman (Abudin nata,2001;17)

Sekarang ini Pendidikan Nasional tengah menghadapi isu krusial, isu yang paling sensitive terkait dengan mutu pendidikan, relevansi pendidikan, akuntabilitas, profesionalisme, efisiensi, debirokrasi dan perilaku pemimpin pendidikan

Pada hakekatnya berbagai upaya yang telah dilakukan pemerintah untuk meningkatkan kualitas pendidikan belum menunjukan hasil yang menggembirakan, karena masih banyak kejadian-kejadian yang tidak mendidik dalam dunia pendidikan sekarang ini, mungkin masalah ini disebabkan antara lain oleh :

a. Manajemen pendidikan yang kurang tepat

b. Penempatan tenaga pendidik yang tidak sesuai dengan bidang keahliannya

c. Pengangkatan kepala sekolah/kepala madrasah yang kurang professional karena lebih mementingkan atau mengutamakan nuansa pilitik di dalamnya

d. Penanganan masalah bukan pada ahlinya

e. Pemerataan kesempatan yang kurang f. Keterbatasan anggaran yang tersedia, sehingga tujuan pendidikan nasional untuk mencerdaskan kehidupan bangsa melalui peningkatan mutu pada setiap jenis dan jenjang pendidikan belum dapat diwujudkan secara signifikan.

Untuk menciptakan sebuah lembaga pendidikan yang bermutu sebagaimana yang diharapkan banyak orang atau masyarakat bukan hanya menjadi tanggung jawab sekolah saja tetapi merupakan tanggung jawab dari semua pihak termasuk orang tua dan dunia usaha.sebagai customer internal dan eksternal dari sebuah lembaga pendidikan. Menurut Arcaro S Jerome menyampaikan bahwa terdapat lima karakteristik sekolah yang bermutu yaitu : 1) Fokus pada pelanggan, 2) Keterlibatan total, 3) pengukuran, 4) komitmen, 5) perbaikan berkelanjutan (2005:38)

Mutu produk pendidikan akan dipengaruhi oleh sejauh mana lembaga mampu mengelola seluruh potensi secara optimal mulai dari tenaga kependidikan, peserta didik, proses pembelajaran, sarana pendidikan, keuangan dan hubungan dengan masyarakat.Pada kesempatan ini lembaga pendidikan islam harus mampu merubah paradigma baru yang berorientasi pada mutu untuk semua aktifitas yang berinteraksi didalamnya.

Pemimpin lembaga pendidikan Islam,khususnya di lingkungan pesantren dan madrasah merupakan motivator, Event Organizer, bahkan penentu arah kebijakan sekolah dan madrasah yang akan menentukan bagaimana tujuan-tujuan pendidikan pada umumnya direalisasikan.

Untuk mewujudkan hal tersebut maka kepala sekolah yang visioner adalah kepala sekolah yang memenuhi kriteria sebagai berikut :

1. Mampu memberdayakan guru-guru untuk melaksanakan proses pembelajaran dengan baik lancar dan produktif

2. Dapat menyelesaikan tugas dan pekerjaan sesuai dengan waktu yang telah ditetapkan 
3. Mampu menjalin hubungan yang harmonis dengan masyarakat sehingga dapat melibatkan mereka secara aktif dalam rangka mewujudkan tujuan sekolah dan pendidikan

4. Berhasil menerapkan prinsip kepemimpinan yang sesuai dengan tingkat kedewasaan guru dan pegawai lainnya di sekolah

5. Bekerja dengan tim manajemen

6. Berhasil mewujutkan tujuan sekolah secara produktif sesuai dengan ketentuan yang telah ditentukan. (E.Mulysa.2004;126).

Pondok pesantren, bila dibandingkan dengan lembaga pendidikan lainnya yang pernah muncul di Indonesia merupakan sistem pendidikan tertua saat ini dan dianggap sebagai produk budaya Indonesia yang Indigenous. Ditegaskan pula oleh Madjid bahwa pesantren adalah lembaga yang merupakan cikal bakal sistem pendidikan Nasionaldari segi historis, pesantren tidak hanya identic dengan makna keislaman, tetapi juga mengandung makna keaslian Indonesia. Pendidikan ini semula pendidikan agama islam yang dimulai sejak munculnya masyarakat islam di Indonesia, yaitu abad ke-13. Pada saat itu pendidikan pesantren merupakan satusatunya lembaga pendidikan yang terstruktur, sehingga pendidikan ini dianggap sekolah bergensi (Masyhud,2003). Di lembaga inilah kaum muslimim Indonesia mengalami doktrin dasar islam, khususnya menyangkut praktek kehidupan dan keagamaan. Ciri umum yang diketahui adalah pesantren memiliki kultur yang khas, cara pengajarannya yang unik, kyai yang biasanya adalah pendiri pondok pesantren, memberikan layanan pendidikan secara kolektif atau bandongan (collective learning process) dan layanan individual atau individual learning process). Pola seperti tersebut diatas ini disebut pondok pesantren salafiyah.

Pada perkembangannya, pondok pesantren merespon positif terhadap pengaruh pendidikan Barat, Asia, dan
Afrika yang mengenalkan sistim sekolah / klasikal, walaupun secara kultur, pembelajaran secara salafiyah tidak sepenuhnya ditinggalkan. Muncul kemudian istilah pondok modern sepertiPondok Modern Gontor Ponorogo. Modern biasa berarti renaissance, aufklarung atau enlighment. Modern berarti pula keterbukaan, perbedaan pendapat, demokrasi, dan sebagainya. Dalam konteks ini, modern bisa berarti " melampui “. keadaan pesantren dan segala penggambarannya tentang dunia pendidikan Islam tersebut, pada zamannya. Para pendiri pondok modern jelas mencita-citakan sebuah modernisasi pemikiran dalam masyarakat Islam. Dan pondok modern merupakan sebentuk harapan bagi pembaharuan pendidikan yang merdeka ( Ushuluddin, 2002:5) Menurutnya, pondok pesantren disebut modern karena memang tampil tidak sama dengan pondok-pondok tradisional atau salafiyah, baik sistim pendidikan dan pengajarannya maupun pola sikap dan pola pikir keagamaannya, meskipun sebenarnya pondok modern tidak bisa menanggalkan kesan " ortodok “ sebagaimana trademark pesantren lain pada umumnya.

$\begin{array}{ccc}\text { Data } & \text { Departemen Agama } \\ \text { menunjukan } & \text { perkembangan } & \text { pondok }\end{array}$ menunjukan perkembangan pondok pesantern luar biasa secara kuantitatif, tercata jumlah pesantren di Indonesia kurang lebih 11.312 buah dengan santri lebih dari 2.737.805 orang (Masyhud, 2003) terdiri dari pesantren salafiyah dan modern. Selain menunjukan tingkat keragaman, orientasi pimpinan pesantren dan independensi kyai, jumlah ini memperkuat argument bahwa pesantren merupakan lembaga pendidikan swastayang sangat mandiri dan sejati merupakan praktik pendidikan berbasis masyarakat (community based education).Melihat keberadaan dan keragaman pondok pesantren ini sebaiknya menjadi catatan pemerintah terutama dalam rangka realisasi gerakan 
peningkatan mutu pendidikan untuk semua. Dan keberadaannya yang menyebar dan meluas bias dijadikan sebagai basis gerakan pemberantasan buta huruf, akselerasi program wajib belajar, dan bisa meningkatkan HDI ( Human Development Index) Indonesia dimata dunia yang saat ini sedang jelek. Dengan demikian pesantren sebagai institusi pendidikan juga ikut berperan dan bertanggungjawab atas pelaksanaan program-program pemerintah.

Pondok pesantren adalah sebuah sistem sosial yang didalamnya terdapat interaksi sosial yang harus dikelola dengan baik agar dapat memenuhi kebutuhan dan mencapai tujuan pendidikan. Keberhasilan mencapai tujuan tidak hanya bergantung pada guru atau staf lainnya, akan tetapi peran pengasuh atau kyai sebagai sentral figur sangat menentukan dalam menciptakan iklim pesantren yang mendukung pelaksanaan proses belajar mengajar.

Setiap lembaga pendidikan termasukpondok pesantren, dituntut untuk memberikan pelayanan sebaik mungkin kepada " pelanggannya ". Agar tugas ini terwujud, pesantren perlu didukung sistem manajemen yang baik. Beberapa ciri sistem manajemen yang baik adalah adanya pola pikir yang teratur (administrative thinking) pelaksanaan kegiatan yang teratur (administrative behaviour), dan penyikapan terhadap tugas-tugas kegiatan secara baik (administrative attitude).

Menurut Mulyasa (2005:24) bahwa kepala sekolah diasumsikan pimpinan pondok pesantren dikenal dengan direktur atau kyai, merupakan salah satu komponen pendidikan yang paling berperan dalam melaksanakan dan meningkatkan kualitas pendidikan.Sedangkan potensi kepala sekolah / kyai jika ditinjau dari tugas dan tanggungjawabnya, lebih ditekankan pada kompetensi manajerial dan kepemimpinan pendidikan. Sebagai manajer sekaligus pemimpin pendidikan, kepala sekolah/ kyai harus: 1) Membina kerja sama yang harmonis dengan stafnya, 2) Membantu para guru untuk memahami kurikulum, 3) Membina hubungan yang baik antara sekolah dengan masyarakat, dan 4) Menyelenggarakan pendidikan dan membinanya.

Untuk menjawab berbagai permasalahan yang ada di lingkungan pendidikan tersebut manajemen mutu terpadu yang akan memberi solusi para professional pendidikan untuk menjawab tantangan masa kini dan masa depan . Karena manajemen mutu terpadu dapat digunakan untuk membangun aliansi antara pendidikan, bisnis dan pemerintah.Manajemen mutu terpadu dapat membentuk masyarakat responsive terhadap perubahan tuntutan masyarakat di era globalisasi ini. Manajemen Mutu Terpadu juga dapat membentuk sekolah yang tanggap dan mampu merespon perubahan yang terjadi di bidang pendidikan demi memberikan kepuasan pada stakeholder.

Mengacu kepada latar belakang masalah diatas, dapat ditegaskan bahwa mutu pendidikan nasional saat ini sedang menghadapi problem yang pelik dan komplek, bukan saja problem-problem rutin-administrasi, tapi kemampuan ketrampilan manajerial pimpinan lembaga pendidikan, perubahan prilaku dan polapimpinan lembaga pendidikan khususnya di lembaga pendidikan Islam, rendahnya partisipasi dan tanggung jawab secara komprehensip tenaga pendidik dan kependidikan, niat yang kurang tulus dalam menjalankan tugas pokok dan fungsi ( TUPOKSI ) yang diemban olehnya atau Tim Work Tenaga pendidik dan Kependidikan, para pelanggan pengguna lulusan menuntut profesionalisme terhadap teori, skill, dan pengalaman yang mereka miliki sesuai dengan tuntutan lapangan. Evaluasi kebijakan pendidikan dan evaluasi pembelajaran yang masih labil dan berubah-ubah akan mempengaruhi kegoncangan pemahaman dan 
ketidaknyamanan pendidik dan tenaga kependidikan.

Untuk menjawab permasalahan atau alternative solusi penyelesaian persoalan pendidikan di Indonesia pemerintah telah berupaya membuat strategi pembanguan pendidikan nasional antara lain menurut Sidi (2001) ada dua belas strategi yaitu :

1. Menerapkan perencanaan berbasis kompetensi lokal.

2. Meningkatkan pemerataan pendidikan.

3. Menetapkan sistem manajemen mutu secara menyeluruh.

4. Meriview kurikulum secara pereodik serta mengembangkan implementasi kurikulum secara kontinyu.

5. Merancang proses penerapan pendekatan dan metode serta isi pendidikan yang memberi kesempatan luas kepada peserta didik dan warga belajar untuk mengembangkan potensi kemampuannya secara luas.

6. Meningkatkan system manajemen sumber pendidikan yang lebih adil dan memadai serta mendayagunakan dan memobilisasi sumber dana secara efisien.

7. Menyusun rambu-rambu kebijakan pengembangan program pendidikan yang luwes.

8. Membuat peraturan perundangan yang mengatur perimbangan peran pemerintah dan nonpemerintah dalam pendidikan secara komprehensif.

9. Mengurangi unit birokrasi yang dipandang kurang bermanfaat.

10. Mengupayakan secara konsisten dukungan dana yang memadai terutama untuk prioritasprogram pendidikan sebagai public goods.

11. Menjaga konsistensi dan berkelanjutan internalisasi nilai-nilai pendidikan nasional diantaratiga pusat pendidikan ; yaitu keluarga, sekolah dan masyarakat, dan

12. Mengkaji pendekatan pembelajaran yang berorientasi pada life skill.

Kesimpulan yang dapat diambil dari

beberapa strategi tersebut adalah pemerintah telah berupaya untuk memberikan solusi efektif terhadap banyaknya persoalan pendidikan di Indonesia, diantaranya adalah merancang pengembangan program pendidikan yang merata dan menyeluruh dengan menggunakan pendekatan pembelajaran berbasis life skill dan kompetensi lokal.

\section{Manajemen Mutu Terpadu(Total Quality Management (TQM))}

Manajemen berasal dari kata " to manage " yang artinya mengatur. Pengaturan dilakukan melalui proses dan diatur berdasarkan urutan dari fungsifungsi manajemen itu, jadi manajemen itu merupakan suatu proses untuk mewujudkan tujuan yang diinginkan.( Hasibuan, 2004: 1)

Manajemen Mutu Terpadu (Total Quality Management) dalam kontek pendidikan merupakan sebuah filosofi metodologi tentang perbaikan secara terus menerus, yang dapat memberikan seperangkat alat praktis kepada setiap institutsi pendidikan untuk memenuhi kebutuhan, keinginan, dan harapan pelanggan, saat ini maupun masa yang akan datang. ( Edward Sallis, 2006:73). Sedangkan Santoso menyampaikan bahwa TQM merupakan suatu sistem manajemen yang mengangkat kualitas sebagai strategi usaha yang berorientasi pada kepuasan pelanggan dengan melibatkan seluruh anggota organisasi ( 2003:4). Total Quality Management merupakan suatu pendekatan dalam menjalankan usaha yang mencoba untuk memaksimalkan daya saing organisasi melalui perbaikan terus menerus atas produk, jasa, manusia, tenaga kerja, proses, dan lingkungan ( Nasution M.N, 2004:18).

Pada hakekatnya tujuan institusi pendidikan adalah untuk menciptakan dan mempertahankan kepuasan para pelanggan dan dalam TQM kepuasan pelanggan ditentukan oleh stakeholder lembaga pendidikan tersebut. Oleh karena hanya dengan memahmi proses dan kepuasan pelanggan maka organisasi dapat menyadari dan menghargai kualitas. 
Semua usaha / manajemen dalam TQM harus diarahkan pada suatu tujuan utama, yaitu kepuasan pelanggan, apa yang dilakukan manajemen tidak ada gunanya bila tidak melahirkan kepuasan pelanggan.

\section{Kerjasama Tim (Team Work) dalam TQM}

Kerjasama tim merupakan unsur yang sangat penting dalam Manajemen Mutu Terpadu. Tim adalah sekelompok orang bekerja secara bersama-sama dan memiliki tujuan bersama yaitu untuk memberikan kepuasan kepada seluruh satakeholders. Kerja tim dalam sebuah organisasi merupakan komponen penting dalam TQM, mengingat kerja tim akan meningkatkan kepercayaan diri, komunikasi dan mengembangkan kemandirian. Kerjasama tim dalam menangani proyek perbaikan atau pengembangan mutu pendidikan merupakan salah satu bagian dari pemberdayaan (empowerment) pegawai dan kelompok kerjanya dengan pemberian tanggungjawab yang lebih besar. Eksistensi kerjasama dalam sebuah lembaga pendidikan sebagai modal utama dalam meraih mutu dan kepuasan stakeholders melalui proses perbaikan mutu secara ber-kesinambungan.

1. Bertanggungjawab pada mutu pembelajaran.

2. Bertanggungjawab pada pemanfaatan waktu para guru, material sertaruang yang dimanfaatkan.

3. Menjadi sarana untuk mengawasi, mengevalusai dan meningkatkan mutu.

4. Bertindak sebagai penyalur informasi kepada pihak manajemen tentang perubahan-perubahan yang dalam proses peningkatan mutu tim.

$$
\text { Faktor-faktor Penghambat Kerja }
$$

Tim:

1. Identitas pribadi anggota tim.

2. Hubungan antara anggota tim.

3. Identitas tim dalam organisasi.
Kesimpulan dapat diambil adalah kerjasama tim merupakan bagian penting dalam sebuah lembaga pendidikan yang secara bersama-sama berusaha untuk meraih mutu dan kepuasan seluruh stakeholder. Kerjasama tim juga diperlukan sebagai upaya perbaikan atau pengembangan mutu pendidikan. Selainn itu, kerjasama tim juga bisa terganggu oleh tiga faktor penghambat kerja tim, seperti identitas anggota, identitas tim, dan hubungan antara anggota tim.

\section{Kunci keberhasilan tim}

Ada tiga komponen saling berkaitan yang mempengaruhi kinerja dalam produktifitas suatu tim, yaitu sebagai berikut:

1. Organisasi secara keseluruhan

Budaya atau kultur suatu organisasi akan menentukan sikap, perilaku dan cara berfikir seluruh anggota dalam mencapai misi dan tujuuan yang dipengaruhi oleh filosofi organisasi, norma, kode etik, system penghargaan dan harapan dari para anggota organisasi.

2. Tim Kerja

Tim kerja mampu mencapai kinerja atau produktivitas yang diharapkan apabila dilakukan dengan adanya peranan dan tanggungjawab yang jelas, mampu melaksanakan manajemen konflik, adanya prosedur operasi yang jelas dan simple, serta pencapaian misi tim.

3. Para individu anggota tim

Sifat individu anggota tim harus memiliki beberapa persyaratan agar kinerjaatau produktivitas meningkat, yaitu : memiliki kesadaran dini untuk bekerjasama dalam mencapai tujuan tim, memiliki apresiasi terhadap perbedaan individual, bersikap empati dan perhatian yang besar dalam penyampaian tugas masing-masing individu anggota tim.

Berikut ini merupakan beberapa strategi yang dapat digunakan untuk meningkatkan kinerja tim dalam 
pencapaian tujuan. (1) Saling ketergantungan. Saling ketergantungan individu dalam sebuah tim sangat penting dalam hal informasi, sumber daya, pelayanan tugas, karena hal ini dapat memperkuat kekompakan tim dalam mencapai kepuasan seluruh stakeholders. (2) Perluasan Tugas. Tim harus diberi tantangan, karena reaksi atau tanggapan terhadap tantangan tersebut membentuk semangat persatuan, kebanggan dan kesatuan tim. (3) Penjajaran (alignment). Rasa individualistis harus dibuang dalam rangka mencapai misi yang bersama. (4) Bahasa yang umum. Dalam pemakaian istilah harus memakai bahasa umum agar supaya meudah dipahami oleh semua anggota tim. (5) Kepercayaan/Respek. Dalam tim harus berusaha membentuk kepercayaan dan respek demi tercapainya kerjasama yang baik. (6) Kepemimpinan. Dalam tim setiap individu memiliki bakat dan kemampuan anggota tim. (7) Ketrampilan pemecahan masalah. Kemampuan memecahkan masalah dalam tim harus dibina karena masalah sering muncul dalam organisasi. (8) Ketrampilan menangani komprontasi/konflik. Dalam Manajemen Mutu Terpadu dibutuhkan ketrampilan menghadapi perbedaan pendapat dan menyampaikan ketidaksetujuan terhadap pendapat orang lain tanpa merusak keharmonisan dalam tim. (9) Penilaian / tindakan. Penilaian dilakukan dengan memantau dan membandingkan apa yang telah dilakukan dengan pernyataan misi dan rencana tindakan yang ada. (10) Penghargaan. Penghargaan atas kesuksesan tim dalam menyelesaikan tugas merupakan motivasi tim untuk bekerja lebih baik dalam mencapai tujuan selanjutnya

Menurut Edward Sallis, efektifitas dapat diukur dengan delapan paramenter. (1) Sebuah tim memerlukan peran anggota yang telah didefinisikan secara jelas.Hal ini penting untuk mengetahui siapa pemimpin tim dan siapa yang menfalisilitator tim. (2) Tim membutuhkan tujuan yang jelas. Tim harus mempunyai arah dan tujuan yang jelas untuk dicapai. Tujuan harus realistis, dapat dicapai dan relevan bagi kepentingan seluruh anggota. (3) Sebuah tim membutuhkan sumberdayasumberdaya dasar untuk beroperasi.Kebutuhan sumber daya dasar adalah manusia, waktu, ruang dan energi. (4) Sebuah tim perlu mengetahui tanggungjawab dan otoritas.Kekecewaan akan lahir jika terdapat pertimbangan yang diabaikan atau jika tim berlebihan dalam menggunakan otoritasnya. (5) Sebelum tim membutuhkan rencana kerja.Rencana mencakup visi, misi tentang langkahlangkah yang dibutuhkan dalam penyelesaian tugas dan sumber daya bagi tim. (6) Sebuah tim membutuhkan seperangkat aturan untuk bekerja.Aturanaturan harus sederhana dan disetujui oleh seluruh anggota tim, mereka adalah tahap penting dalam penentuan norma. (7) Tim perlu menggunakan alat-alat yang tepat untuk mengatasi masalah dan menemukan solusinya. (8) Tim perlu mengembangkan sikap tim yang baik dan bermanfaat.

Ada beberapa hal yang secara ideal harus dilakukan oleh seluruh anggota dan mencakup kemampuan untuk Menghinisiasikan diskusi, (2) Mencari informasi dan opini. (3) Mengusulkan prosedur untuk mencapai tujuan. (4) Menjelaskan atau mengurangi ide. (5) Menyimpulkan. (6) Tes untuk mufakat. (8) Bertindak sebagai moderator lalu lintas percakapan langsung, menghindari percakapan simultan, menghambat pembicaraan yang dominan, memberi kesempatan pada pembicara uyang lain, menjaga percakapan dari hal-hal yang menyimpang. (9) Kompromis dan kreatif dalam mengatasi perbedaan. (10) Mencoba untuk mengurangi ketegangan dalam kelompok dan berusaha bekerja menembus masalah - masalah yang sulit. (11) Mengekpresikan perasaan kelompok dan meminta yang lain untuk mengecek kesan tersebut. (12) Membuat kelompok setuju terhadap standar. (13) Merujuk pada 
dokumentasi dan data. (14) Memuji dan mengoreksi anggota dengan cara yang fair dan mampu menerima komplain sama baiknya dengan pujian.

\section{Keterlibatan Stakeholders dalam TQM}

Misi utama dari Manajemen Mutu Terpadu adalah untuk memenuhi kebutuhan dan tuntutan seluruh pelanggan.Sekolah yang baik adalah sekolah yang mampu menjaga hubungan dengan pelanggannya dan memiliki obsesi terhadap mutu.

Pelanggan sekolah ada dua macam:

1. Pelanggan Internal : guru, pustakawan, laboratorium, teknisi dan administrasi.

2. Pelanggan Eksternal terdiri dari:

a. Pelanggan primer : siswa

b. Pelanggan sekunder: orang tua, pemerintah dan masyarakat.

c. Pelanggan tertier : pemakai/penerima lulusan (perguruan tinggi dan dunia usaha).

Menurut Edward Sallis dalam institusi pendidikan pelanggan utama adalah pelajar yang secara langsung menerima jasa, pelanggan kedua yaitu orang tua atau sponsor pelajar yang memiliki kepentingan langsung secara individu maupun institusi dan pelanggan ketiga yaitu pihak yang memiliki peran penting, meskipun tak langsung seperti pemerintah dan masyarakat secara keseluruhan.

Guru, staf dan setiap orang yang bekerja dalam masing-masing institusi turut memberikan jasa kepada para kolega mereka adalah pelanggan internal. Hubungan internal yang kurang baik akan menghalangi perkembangan sebuah institusi sekolah dan akhirnya membuat pelanggan eksternal menderita. Salah satu tujuan TQM adalah untuk merubah sebuah institusi sekolah manjadi sebuah tim yang ikhlas, tanpa konflik, dan kompetisi internal, untuk meraih sebuah tujuan tunggal yaitu memuaskan seluruh pelanggan.

\section{Keterlibatan Siswa dalam TQM}

Upaya melibatkan siswa telah menjadi fenomena yang berkembang pada sekolah akhir-akhir ini, tetapi belum maksimal siswa yang terlibat dan mempengaruhi proses penyusunan kegiatan belajar mengajar disekolah. Perlu didesain agar supaya dalam penyusunan kurikulum dan peraturan-peraturan disekolah disusun secara fair dan efektif dengan melibatkan siswa.Adalah penting melibatkan siswa dalam proses pembuatan keputusan seperti dalam penyusunan kurikulum dan hal - hal yang berkenaan dengan desain materi pembelajaran. Sebuah lingkungan kelas yang memberi otonomi atau keleluasaan bagi siswa memiliki kaitan erat dengan kemampuan siswa dalam berekspresi, kreatif menunjukkan kemampuan diri belajar secara konseptual dan senang terhadap tantangan.Si siswa yang memiliki andil dalam kegiatan-kegiatan instrusional atau pembuatan peraturan sekolah memilik rasa cinta terhadap sekolah dan pada gilirannya secara signifikan keterlibatan mereka terhadap kegiatan - kegiatan sekolah.

Selama ini siswa dijadikan obyek dikelas ketimbang dijadikan sebagai subyek pendidikan.Siswa diharuskan tunduk kepada seluruh aturan yang dibuat oleh sekolah siswa tidak diberi kesempatan untuk mengungkapkan kemampuan yangdimilinya. Siswa dalam menerima pelajaran dari guru dan menjalankan peraturan yang ada disekolah dalam keadaan terpaksa, karena merasa tidak nyaman dan tidak dilibatkan dalam desain pembelajaran dan pembuatan peraturan.Bahwa orientasi negatif bisa muncul jika kebijakan, tujuan dan norma sekolah atau implementasi semuanya dikembangkan tanpa melibatkan siswa atau siapa saja yang akan melaksanakannya. Sebaliknya keterlibatan mereka yang maksimal, terutama siswa 
akan memberikan respon positif terhadap program, peraturan, tuntutan atau normanorma sekolah,keterlibatan siswa dalam perencanaan aktifitas kelas adalah merupakan bagian dari aspek otonomi dan kontrol dari siswa sendiri. Jika siswa merasa tidak berseberangan dengan aturan kelas, kemungkinan besar mereka akan mengembangkan prilaku positif terhadap sekolah secara umum dan terhadap prestasi akademis secara khusus.

\section{Keterlibatan Orang Tua dalam TQM}

Keterlibatan orang tua dalam proses pendidikan anak disekolah merupakan hal yang penting dilakukan oleh institusi pendidikan dan inilah salah satu unsur penting TQM. Peran orang tua dalam pembentukan motivasi dan penguasaan diri anak sejak dini merupakan modal besar bagi kesuksesan anak di sekolah. Peran orang tua terdiri dari: orang tua dapat mendukung perkembangan intelektual anak dan kesuksesan akademik anak dengan memberi mereka kesempatan dan akses ke sumber-sumber pendidikan seperti jenis sekolah yang dimasuki anak atau akses ke perpustakaan, multi media seperti internet dan televisi pendidikan. Orang tua dapat membentuk perkembangan kognitif anak dan pencapaian akademik secara langsung dengan cara terlibat langsung dalam aktivitas pendidikan mereka. Orang tua juga mengajarkan anak norma dalam berhubungan dengan orang dewasa dan teman sebaya yang relevan dengan suasana kelas.

Alternatif cara untuk mengakrabkan
antara sekolah dan orang tua yaitu:
Sekolah dan orang tua dapat melakukan komunikasi secara intensif dan proaktif dengan cara sekolah menghubungi orang tua Siswa. Ini dapat dilakukan dengan (1) Mengirimkan ucapan selamat bergabung dengan sekolah dan BP2, bagi orang tua siswa baru, setelah perlu dilakukan perkenalan dan orientasi singkat agar orang tua mengetahui sekolah dengan aktivitasnya. (2) Melakukan rapat tertentu, sebaiknya dilakukan pada level kelas, sehingga diantara rapat dapatefektif dan orang tua dapat saling kenal. (3) Mengirimkan berita sekolah secara periodik, sehingga orang tua selalu mengetahui perkembangan terakhir. (4) Membagikan daftar personal sekolah secara lengkap, termasuk alamat dan tugas-tugaspokok mereka, sehingga orang tua dapat menghubungi. (5) Mengundang orang tua jika anaknya berprestasi, jangan hanya mengundang kalau anaknya bermasalah. (6) Melakukan kunjungan rumah bila diperlukan yaitu melibatkan orang tua sebagai sponsor/panitia kegiatan di sekolah, memberi peran orang tua untuk mengambil keputusan, sehingga merasa bertanggung jawab untuk melaksanakannya, mendorong guru untuk melibatkan orang tua dalam menunjang keberhasilan belajar siswa dan usaha yang dapat dilakukan untuk mendorong orang tua terlibat pada kegiatan di sekolah. (7)Melakukan identifikasi kebutuhan sekolah dan bagaimana orang tua dapat membantu pada kegiatan tersebut. Libatkan guru, staf dan wakil BP3/ komite dalam identifikasi tersebut.Susun uraian tugas untuk posisiposisi yang mungkin dapat dibantu oleh orang tua sebagai relewan.Upayakan tugas tersebut tidak terikat oleh jadwal waktu yang ketat. (8)Membantu guru untuk menyusun program relawan yang terkait dengan tugasnya. (9) Menginformasikan secara luas program relawan tersebut, lengkap dengan diskripsi tugasuntuk setiap tugas/posisi. (10)Mengundang orang tua yang bersedia menjadi relawan. (11)Memberikan penghargaan bagi orang tua yang telah melaksanakan tugas sebagai relawan.

\section{PENUTUP}

Mempertahankan kepuasan pelanggan membuat organisasi dapat menyadari dan menghargai kualitas. Semua usaha / manajemen dalam TQM harus diarahkan pada suatu tujuan utama, yaitu kepuasan pelanggan, apa yang 
dilakukan manajemen tidak ada gunanya bila tidak melahirkan kepuasan pelanggan.

Kerjasama tim dalam menangani proyek perbaikan atau pengembangan mutu pendidikan dilakukan melalui pemberdayaan (empowerment) pegawai dan kelompok kerjanya dengan pemberian tanggungjawab yang lebih besar. Eksistensi kerjasama dalam sebuah lembaga pendidikan sebagai modal utama dalam meraih mutu dan kepuasan stakeholders melalui proses perbaikan mutu secara berkesinambungan

Guru, Staf dan setiap orang dalam institusi pendidikan turut memberikan jasa kepada para kolega mereka sesama pelanggan internal. Hubungan internal yang kurang baik akan menghalangi perkembangan sebuah institusi. Salah satu tujuan TQM adalah untuk merubah sebuah institusi sekolah menjadi sebuah tim untuk meraih sebuah tujuan tunggal yaitu memuaskan seluruh pelanggan. Peran orang tua dalam motivasi diri anak sejak dini merupakan modal besar bagi kesuksesan anak di sekolah.Orang tua dapat mendukung perkembangan intelektual anak dan kesuksesan akademik anak dengan memberi mereka kesempatan dan akses ke sumber-sumber pendidikan.

\section{DAFTAR PUSTAKA}

Anwar, 2004, Pendidikan $\begin{array}{r}\text { Kecakapan } \\ \text { Hidup (Life }\end{array} \begin{array}{r}\text { Skills } \\ \text { Education), Bandung: Penerbit } \\ \text { Alfabeta }\end{array}$
AryBogdan,
Bihlen,SK, 1982,Qualitative
Reseach For Education An
Introduction to Theory and
Methods, London,Allyn and
Bacon,Inc.
BSNP, 2006, Panduan Penyusunan
Kurikulum Tingkat Satuan
Pendidikan Jenjang Pendidikan
Dasardan Menengah, Jakarta.

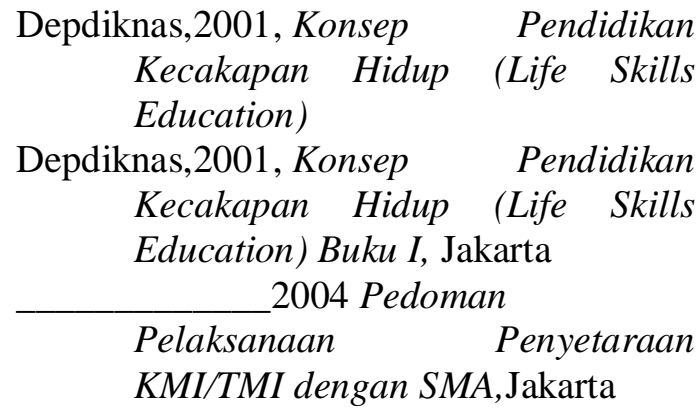

Dirjen Kelembagaan Agama Islam Depatremen Agama,2005,Pedoman Integrasi Life Skills Dalam Pembelajaran, Jakarta

Edward Sallis, ( 2006 ) Total Quality Management, Alih Bahasa, Ahmad Ali Riyadi. Ircisod, Yogyakarta.

Handoyo, T. Hani, 2003, Manajemen Edisi 2, Yogyakarta: BPFE-Yogyakarta

Hidayati, Titiek Rohana, 2005,Hubungan antara Ketrampuilan Manajerial Kepala Sekolah, pelatihan Guru, Motivasi Kerja dan Iklim Organisasi dengan Kinerja Guru Madrasah Aliyah Swasta se kabupaten jember, Unpublished Dissertation, malang:UM Malang.

Irfan, Mohamad, 1997, Pengelolaan Ketrampilan di Pondok Pesantren Nurul Jadid paiton Probolinggo, Unpublished Thesis, Malang, PPS IKIP Malang

Kaluge, Laurens, 2003, Sendi - sendi manajemen

Pendidikan, Surabaya;UNESA University Press

Mulyasa, E, 2002 Kurikulum Berbasis Kompetensi, Konsep, Karakteristik, dan Implementasi, Bandung: PT. Remaja Rosdakarya

Nazir,Moh,2005, Metode

Penelitian., Bogor: Penerbit Ghalia Indonesia

Nasution.M.N. ( 2004 ) Manajemen Mutu Terpadu, Ghalia Indonesia.

Peraturan Menteri Pendidikan Nasional Nomor 23 tahun 2006 Tentang Standar Kompetensi Lulusan Untuk Satuan Pendidikan Dasar dan Menengah,Jakarta 
Pidarta, made,2004, Manajemen

Pendidikan Indonesia, Jakarta:

Penerbit Rineka Cipta

Suryadi Prawirosentono, 2002, Filosofi

Baru Tentang Manajemen Mutu Terpadu, Jakarta, PT.Bumi Aksara.

Sidi, 1, 2001, Strategi Pendidikan Nasional, Makalah, disampaikan pada simposium dan musyawarah Nasional 1 Alumni Program Pascasarjana Universitas Negeri Malang tanggal 13-14 oktober 2001 di Malang.

Syafrudin, 2002, Manajemen Mutu Terpadu Dalam Pendidikan Konsep, Strategi dan Aplikasi, Jakarta, PT.Grasindo .

Stephen M. and Colin Morgan, 1993, Total Quality Mangement and The School, Open University Press, Buckingham-Philadelphia.

Surya Subrata ( 2004 ) Manajemen Pendidikan di Sekolah, Jakarta. PT.Rineka Cipta.

Sumahamijaya, Suparman dkk,2003, Pendidikan Karakter Mandiri dan Kewiraswastaan, Suatu upaya bagi keberhasilan Program Pendidikan Berbasis Luas/BBE dan Life Skills, Bandung : PT Angkasa

Ushuluddin, Win, 2002, Sintesis Pendidikan Islam Asia Afrika,Yogyakarta: Paradigma

Wahjosumidjo, 2001, Kepemimpinan dan Motivasi, Jakarta: Ghalia Indonesia

2003, Kepemimpinan Kepala Sekolah Tinjauan Teoritik dan Permasalahannya, Jakarta : PT Raja Grafindo Persada

$\begin{array}{cr}\text { Zarkasyi, } \quad \text { Abdullah } & \text { Syukri, } \\ \text { 2003, Manajemen } & \text { Pesantren, } \\ \text { Pengalaman Pondok } & \text { Modern } \\ \text { Gontor, Ponorogo:Trimurti Press }\end{array}$

